\title{
Pengembangan Kuliner Kue Lumpang Khas Daerah Lahat Guna Melestarikan Kuliner Asli Daerah
}

Yudi Saputra $^{1)}$, ${ }^{*}$ Lesi Hertati ${ }^{2}$, Lilis Puspitawati ${ }^{3)}$, Rilla Gantino ${ }^{4)}$, Meifida Ilyas ${ }^{5)}$

${ }^{1)}$ Mahasiswa Akuntansi Universitas Indo Global Mandiri Palembang Sumatera Selatan

${ }^{2)}$ Fakultas Ekonomi Akuntansi, Universitas Indo Global Mandiri Palembang-Indonesia

${ }^{3)}$ Fakultas Ekonomi Akuntansi Universitas Komputer Bandung-Indonesia

${ }^{4)}$ Fakultas Ekonomi Akuntansi Universitas Esa Unggul Jakarta-Indonesia

${ }^{5)}$ Fakultas Ekonomi Akuntansi Universitas Satya Negara Jakarta-Indonesia

Email: hertatilesi@yahoo.co.id² ; lilis.puspitawati@email.unikom.ac.id ${ }^{3}$; rilla.gantino@esaunggul.ac.id ${ }^{4}$; meifidacantique@yahoo.com ${ }^{5}$

\section{Cara Mensitasi Artikel ini:}

Saputra, Y., Hertati, L., Puspitawati, L., Gantino, R., \& Ilyas. M. (2021). Pengembangan kuliner kue lumpang khas daerah Lahat guna melestarikan kuliner asli daerah. ABDIMASY: Jurnal Pengabdian dan Pemberdayaan Masyarakat, 2(1), 46-52. https://doi.org/10.46963/ams.v2i1.335

\section{Sejarah Artikel}

Diterima : 08/06/2021

Direvisi : :25/06/2021

Diterbitkan : 30/06/2021

*) Corresponding Author

hertatilesi@yahoo.co.id

\section{DOI}

https://doi.org/10.46963/ams.v2i1.335

Kata Kunci:

Kuliner Lokal; Kue Lumpang;

Makanan Khas Lahat

Keywords:

Traditional Culinary; Lahat;

Lumpang Cake

\section{Editorial Address}

Kampus Panam (Parit Enam)

STAI Auliaurrasyidin, Jl. Gerilya

No. 12 Tembilahan Barat, Riau,

Indonesia, 29213

abdimasy@stai-tbh.ac.id
Abstract: Traditional culinary is culinary food that has been around for a long time and is difficult to find in other areas. Besides the taste and shape, not everyone can make it so that the taste is different. Lahat is a city located in the province of South Sumatra. The city named Bumi Seganti Setungguan has many special foods and culinary mainstays that are not inferior to other areas in South Sumatra. The Lumpang cake is a traditional cake made from rice flour. This delicious cake with a sweet taste has been around for 80 years and is still popular. This cake is sprinkled with coarsely grated coconut which adds a savory when eating it. This cake, which includes market snacks, is perfect for drinking tea.

Abstrak: Kuliner khas adalah kuliner makanan yang sudah lama dan sulit ditemukan di daerah lain, selain citra rasa, bentuk dan tidak semua orang bisa membuatnya sehingga cita rasanya berbeda. Lahat adalah sebuah kota yang terletak di Provinsi Sumatera Selatan. Kota dijuluki Bumi Seganti Setungguan memiliki banyak makanan khas dan kuliner andalan yang tidak kalah dengan daerah-daerah di Sumatera Selatan lainnya. Kue lumpang adalah kue tradisional berbahan dasar tepung beras. Kue lezat dengan rasa manis ini telah ada sejak 80 tahun silam dan masih digemari hingga saat ini. Kue ini ditaburi parutan kelapa kasar yang menambah rasa gurih saat memakannya. Kue yang termasuk jajanan pasar ini sangat cocok untuk teman minum teh.

This work is licensed under a Creative Commons Attribution-ShareAlike 4.0 International License (CC-BY-SA)

\section{PENDAHULUAN}

Keanekaragaman olahan masakan yang menjadi ciri khas daerah sering disebut makanan khas daerah. Makanan khas daerah adalah makanan yang biasanya di konsumsi di suatu daerah tersebut. Karakter suatu masakan daerah biasanya mencerminkan karakter masyarakatnya. Kabupaten Lahat adalah salah satu kabupaten di Provinsi Sumatra 
Pengembangan Kuliner Kue Lumpang Khas Daerah Lahat Guna Melestarikan .....

Selatan yang terdiri dari 7 kecamatan induk yaitu Lahat, Kikim, Kota Agung, Jarai, Tanjung Sakti, Pulau Pinang, dan Merapi. Namun pasca pemekaran, jumlah Kecamatan di Kabupaten Lahat bertambah menjadi 22 kecamatan.

Sekitar tahun 1830 pada masa kesultanan Palembang, di Kabupaten Lahat telah ada marga, marga-marga ini terbentuk dari sumbai-sumbai dan sukusuku yang ada pada waktu itu seperti Lematang, Besemah, Lintang, Gumai, Tebing Tinggi, dan Kikim. Marga merupakan pemerintahan bagi sumbaisumbai dan suku-suku. Marga inilah merupakan cikal bakal adanya Pemerintah di Kabupaten Lahat.

Pada masa Inggris berkuasa di Indonesia, marga tetap ada. Pada masa kekuasaan Belanda sesuai dengan kepentingannya pada waktu itu, pemerintahan di Kabupaten Lahat dibagi dalam afdeling (Keresidenan) dan onder afdelling (kewedanan). Dari 7 afdelling yang terdapat di Sumatra Selatan, di Kabupaten Lahat terdapat 2 (dua) afdelling yaitu afdelling Tebing Tinggi dengan 5 (lima) daerah onder afdelling, dan afdelling Lematang Ulu, Lematang Ilir, Kikim serta Besemah dengan 4 onder afdelling. Dengan kata lain, (waktu itu) di Kabupaten Lahat terdapat 2 keresidenan.

Pada tanggal 20 Mei 1869 afdelling Lematang Ulu, Lematang Ilir, serta Besemah beribu kota di Lahat dipimpin oleh PP Ducloux, dan posisi marga sebagai bagian dari afdelling. Tanggal 20 Mei akhirnya ditetapkan sebagai hari jadi Kabupaten Lahat sesuai dengan Keputusan Gebernur Kepala Daerah
Tingkat I Sumatra Selatan No. 008/SK/1998 tanggal 6 Januari 1988.

Masuknya tentara Jepang pada tahun 1942, afdelling yang dibentuk oleh Pemerintah Belanda diubah namanya menjadi sidokan. Sidokan ini dipimpin oleh orang pribumi atas penunjukan pemerintah militer Jepang dengan nama Gunco dan Fuku Gunco. Kekalahan Jepang pada tentara sekutu pada tanggal 14 Agustus 1945 dan bangsa Indonesia memproklamasikan kemerdekaannya pada tanggal 17 Agustus 1945, maka Kabupaten Lahat merupakan salah satu kabupaten di Provinsi Sumatra Selatan berdasarkan UU No. 22 Tahun 1948, Keppres No. 141 Tahun 1950, PP Pengganti UU No. 3 Tahun 1950 tanggal 14 Agustus 1950.

Kabupaten Lahat dipimpin oleh $\mathrm{R}$. Sukarta Marta Atmajaya, kemudian diganti oleh Surya Winata dan Amaludin dan dengan PP No. 1959 tentang Pembentukan Daerah Tingkat II dalam Tingkat I provinsi Sumatra Selatan, sehingga Kabupaten Lahat resmi sebagai Daerah Tingkat II hingga sekarang, dan diperkuat dengan UU No. 22 Tahun 1999 tentang Otonomi Daerah dan diubah dengan UU No. 32 Tahun 2004 menjadi Kabupaten Lahat.

Lahat memiliki makanan khas yang sangat lezat seperti Pindang Patin, Pindang Tempoyak, Hehancang Tehung, Lempok durian, gulai rebung. Sedangkan di jajaran kuenya ada Maksuba dan ada juga kue Lumpang.

Kegiatan pengabdian ini bertujuan untuk meningkatkan pemahaman masyarakat desa dalam melestarikan makanan khas adat daerah. Serta tetap 
menjaga citra rasa olahan makanan khas daerah masyarakat di Kabupaten Lahat, Sumatera Selatan dalam kuliner lokal kue lumpang makanan khas daerah lahat.

Adapun manfaat dari kegiatan pengabdian ini adalah:

1. Meningkatkan pengetahuan dan pemahaman masyarakat tentang pentingnya melestarikan makanan khas adat daerah

2. Mengembangkan SDM dalam pengolahan makanan khas adat daerah yang sudah mulai sulit didapat.

3. Meningkatkan manajemen pemasaran dalam promosi makanan khas yang begitu unik.

4. Mengenalkan dengan masyarakat luas bahwa makan khas kue lupang asal mulanya dibuat dari bahan-bahan yang alami dan manual.

\section{METODE}

Kegiatan pengabdian ini menggunakan anggaran mandiri tim pengabdi. Pengaturan jadwal sosialisasi disesuaikan dengan protokol kesehatan yang ketat dan sebagian kegiatan memanfaatkan media virtual dalam kegiatan sosialisasi.

Metode pelaksanaan terdiri dari tahapan kegiatan sosialisasi, pengajaran, aplikasi, dan evaluasi. Pada tahapan sosialisasi diberikan Pelatihan berkumpul di rumah masyarakat. Tahapan ketiga diberikan pelatihan memasak kue lumpang. tahap akhir adalah tahapan evaluasi, di mana diberikan pemahaman dan solusi pelestarian kue adat daerah. Indikator pelaksanaan berupa Kuesioner pre-test dan post-test serta kemampuan dan tingkat pemahaman dalam menguasai pangsa pasar.
Keberhasilan sosialisasi dapat dilihat dari hasil jawaban kuesioner pre-test (sebelum sosialisasi) dan post-test (sesudah sosialisasi) dengan tingkat keberhasilan $100 \%$, sedangkan bagi masyarakat yang buta aksara pengisian kuesioner akan dibimbing oleh tim Sosialisasi. Pengabdian masyarakat ini menggunakan biaya secara pribadi tidak ada rincian tabel biaya dan banyak dilakukan dengan virtual dikarenakan musim wabah Covid-19 dan jarak yang cukup jauh.

Kegiatan Pelaksanaan Pengabdian Kepada Masyarakat ini dilakukan pada bulan Februari Maret, dan awal Juni 2021.

Lokasi pengabdian pada masyarakat ini berada pada gambar peta seperti tampak di bawah ini:

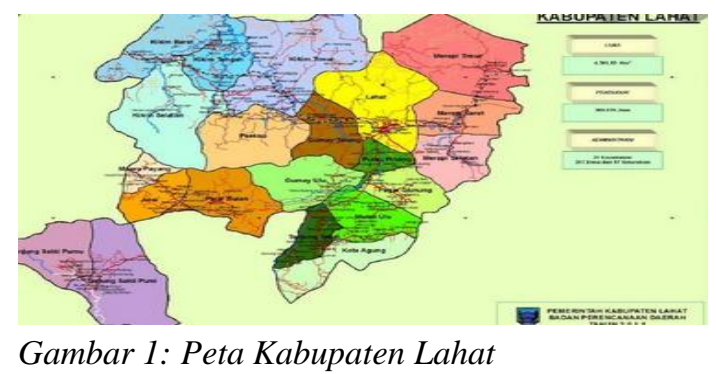

\section{HASIL DAN PEMBAHASAN}

Pada tahapan pertama kegiatan, tim melakukan wawancara sembari membagikan kuesioner, masyarakat menjawab kuesioner pre-test yang dibuat dalam bentuk hard copy. Waktu yang diberikan kepada masyarakat untuk menjawab kuesioner pre-test yaitu lebih kurang 5 menit. Selanjutnya, tim menjelaskan terkait tujuan, maksud diadakannya penyuluhan, dan menjelaskan materi tentang "Kuliner 
Yudi Saputra, Lesi Hertati, Lilis Puspitawati, Rilla Gantino, \& Meifida Ilyas

Pengembangan Kuliner Kue Lumpang Khas Daerah Lahat Guna Melestarikan .....

Lokal Kue Lumpang Makanan Khas Daerah Lahat"

Masyarakat terlihat antusias mengikuti penyuluhan terutama saat dijelaskan terkait kuliner masyarakat lokal kue Lumpang makanan khas daerah Lahat guna melestarikan masakan asli daerah. Setelah pemaparan materi, dilakukan tanya jawab selama lebih kurang 15 menit. Tanya jawab berlangsung cukup menarik.

Tahap terakhir dilakukan evaluasi berupa penyebaran kuesioner post-test untuk melihat sejauh mana pemahaman masyarakat terhadap materi yang dipaparkan. Sama halnya dengan pre-test, post-test berlangsung selama 5 menit. Pre-test dan post-test menggunakan skala likert dengan rincian yaitu sangat tidak paham (1), tidak paham (2), cukup paham (3), paham (4), sangat paham (5).
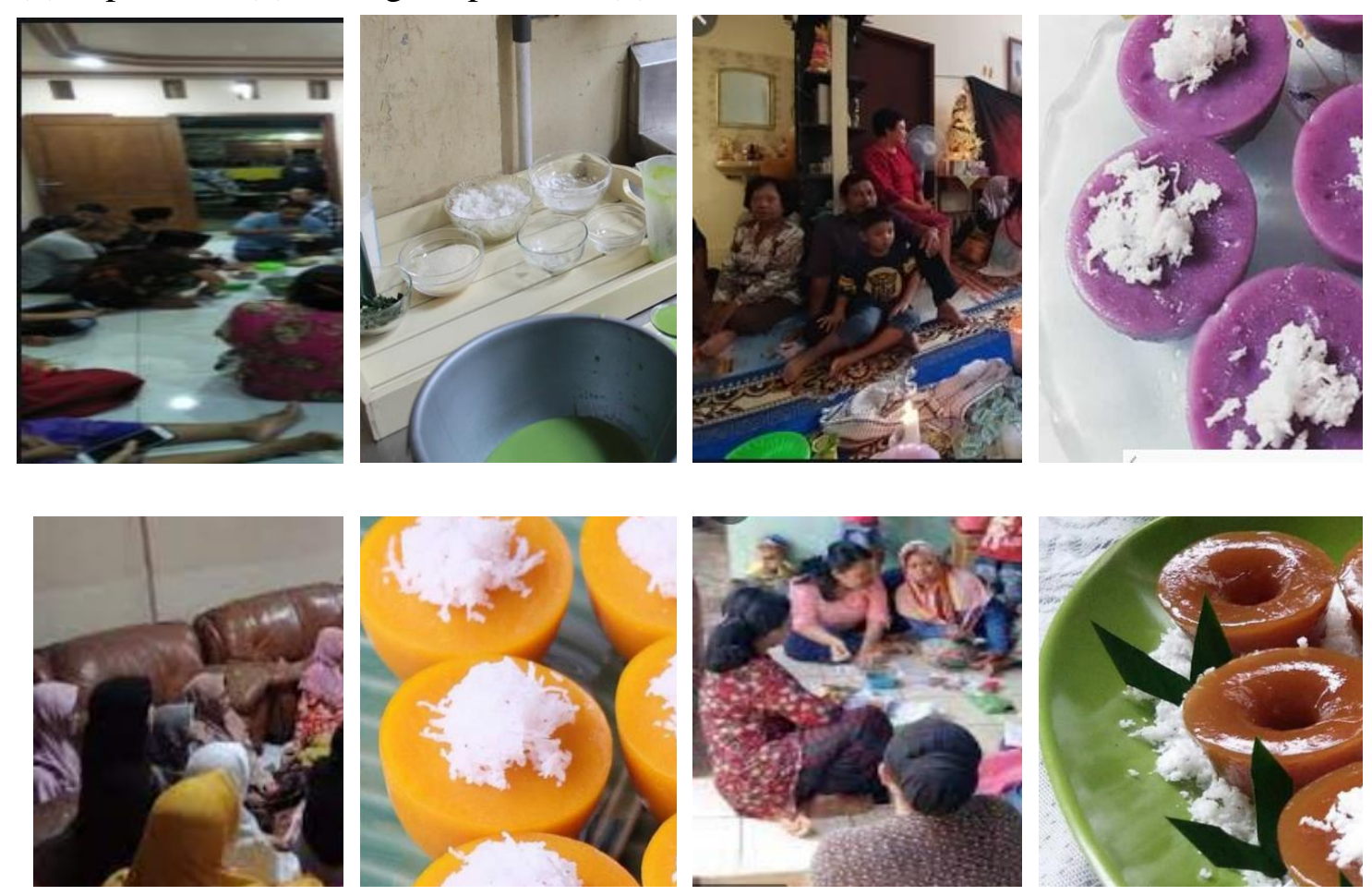

Gambar 3 : Kue Lumpang

Kue tradisional ini sudah sangat dikenal dengan kelezatannya. Nama

lumpang karena kue ini mempunyai bentuk yang sama dengan lumpang atau 
alat penumbuk padi yang terbuat dari kayu atau batu.

Memiliki rasa yang manis menjadikan jajanan favorit untuk warga lokal. Selain dari rasanya, kue lumpang ini sangat padat sehingga mengenyangkan meskipun hanya memakan 1 saja.

Kudapan ini berbahan dasar tepung beras, perisa pandan, gula pasir, dan santan. Adonan kemudian dicampur dengan sedikit air kapur untuk mendapatkan tekstur yang kenyal. Disajikan dengan parutan kelapa di atasnya sehingga menambah rasa gurih. Dimasak dengan di kukus, menjadikan kue ini sehat dan cocok bagi yang sedang diet.

Sekarang, kue lumpang tidak hanya memiliki warna hijau yang berasal dari daun suji dan daun pandan, tetapi ada yang berwarna coklat dari gula merah, atau warna ungu dari ubi. Kue lumpang berwarna hijau biasa dihidangkan bersama parutan kelapa gurih yang diberi garam kemudian dikukus.

Berdasarkan sejarahnya, kue lumpang sudah dijual di Palembang lebih dari 80 tahun yang lalu. Kue lumpang pada awalnya dijual oleh para pedagang keliling yang berjalan dari kampung ke kampung. Nama kue lumpang ini terinspirasi bentuknya yang mirip dengan lumpang, atau wadah untuk menumbuk padi. Kue lumpang memiliki bentuk bulat dengan bagian cekung di tengahnya yang memiliki kemiripan dengan lumpang. Lumpang ini digunakan masyarakat Palembang untuk menumbuk padi, kopi maupun bahan dapur lainnya.

Kue lumpang sangat mudah dibuat. Apalagi bahan-bahannya yang juga mudah didapat. Seperti 25 gram tepung beras, 100 gram tepung tapioka, $250 \mathrm{ml}$ santan, 5 lembar daun pandan, 3 lembar daun suji, garam secukupnya dan 100 gram gula pasir.

Langkah pertama yang harus dilakukan adalah melarutkan santan, daun suji, daun pandan dan gula pasir dengan cara diblender. Campuran tersebut akan menghasilkan adonan dengan warna hijau pekat. Kemudian saring adonan berwarna hijau tersebut dan masukkan ke dalam wadah yang berisi tepung tapioka dan tepung beras, aduk adonan tersebut sampai merata secara keseluruhan sambil diberi garam secukupnya.

Selanjutnya masukkan adonan kue lumpang ke dalam cetakan mungil. Dari takaran yang sudah ditentukan di atas, dapat menghasilkan kue lumpang sebanyak 15 kue. Langkah selanjutnya adalah dengan mengukus adonan tersebut selama sekitar 30 menit. Kue ini terbilang unik, karena saat proses kukus, adonan kue lumpang akan secara otomatis membentuk lubang di tengahnya.

Tekstur kue lumpang yang lumer dengan cita rasanya yang manis sedikit agak gurih juga menjadi daya tarik bagi semua orang, (Andi \& Sadat, 2009).

Peminat olahan kue lumpang pandan memang begitu besar di kalangan masyarakat bahkan mulai dari kalangan anak-anak hingga orang dewasa pun juga sangat menyukai jenis kue tradisional satu ini. Tampilan warna kue lumpang yang hijau memang sangat menarik sekali. Jika olahan kue lumpang pandan dijadikan sebagai pilihan utama dalam menjalankan kegiatan usaha. 
Pengembangan Kuliner Kue Lumpang Khas Daerah Lahat Guna Melestarikan .....

Usaha produksi kue lumpang pandan memang begitu menguntungkan, hal ini bisa dipastikan karena jenis kue tradisional ini memiliki penggemar dimasyarakat. Peluang bisnis kue lumpang pandan pun kini juga masih terbuka sangat luas bagi pelaku bisnis tersebut (Geertz \& Clifford, 1983; Pateda, Mansoer. 2010).

Penentuan harga kue lumpang termasuk jajanan tradisional yang kini telah banyak disukai oleh semua kalangan. Bahkan jajanan basah satu ini juga sering dijumpai dengan harga yang terjangkau.

Penentuan lokasi usaha kue lumpang pandan bisa dijalankan di mana saja tempatnya, asalkan berada di tempattempat yang strategis. Hal ini harus dilakukan supaya nantinya bisa membuat bisnis kue lumpang pandan mudah diketahui masyarakat luas. Sebenarnya pemilihan tempat untuk berbisnis kue lumpang pandan memang banyak sekali diawali dengan membuka stan kecil yang berada di lokasi seperti di pasar malam, di dekat tempat rekreasi, dekat kampus, dekat kos-kosan, dekat pusat kota, dekat alon-alon, dekat sekolah dan tempat strategis yang lain., Widiya, Hertati, Puspitawati, Gantino, Ilyas, 2021).

Dari segi pemasaran, strategi pemasaran kue lumpang pandan dapat dilakukan dengan cara membuat cita rasa kue lumpang pandan yang nikmat. Pemasaran bisnis kue lumpang pandan kini juga bisa dilakukan dengan memanfaatkan melalui media sosial agar keberadaan bisnis kue lumpang pandan mudah diketahui masyarakat luas dan bisa berjalan lebih lancar. Beberapa media sosial yang dapat dimanfaatkan untuk memasarkan usaha kue lumpang pandan diantaranya BBM, line, facebook, twitter, path dan berbagai macam jejaring sosial yang lain, (Harsojo, 1988).

Kue lumping bisa mejadi solusi mandiri untuk berusaha mencegah kemiskinan. Kemiskinan merupakan suatu masalah yang dihadapi oleh manusia, dengan kata lain bahwa kemiskinan merupakan suatu masalah sosial yang sifatnya mendunia dan melibatkan berbagai kehidupan manusia. (Kanada \& Rabial, 2012; Hertati, Puspitawati, Gantino, Ilyas, 2021; Rokian, Ajmal. 2014).

\section{SIMPULAN}

Permasalahan kemiskinan pada saat ini sangatlah menjadi persoalan bangsa Indonesia, kemiskinan telah menjadi isu global dari mana setiap negara merasa berkepentingan untuk membahasnya. Berkaitan dengan penanganan kemiskinan di era globalisasi maka sering timbul permasalahan yang dihadapi oleh bangsa Indonesia dengan adanya pengangguran dimana-mana penyebab kemiskinan yang tidak dapat di elakkan lagi dengan tingginya pertumbuhan ekonomi yang berdampak pada kemiskinan. Setiap daerah mempunyai keunggulannya masing-masing. Entah itu dari budaya, keindahan alam, atau dari kulinernya yang khas, contohnya dari yang kami bahas,

Kabupaten Lahat tidak hanya mempunyai hutan dan bukit yang elok untuk di pandang, tapi Lahat juga mempunyai makanan khas yang sangat lezat, salah satunya Kue Lumpang, kue khas Lahat, yang mudah dijumpai dipasar atau di toko kue, serta kue ini juga bisa 
dibuat sendiri di rumah karna proses pembuatannyapun sangatlah mudah, jadi sudah selayaknya kita melestarikan makanan-makan lokal yang tak kalah lezat dengan makanan-makan kekinian, supaya keturunan kita nanti masih bisa merasakan betapa lezatnya makan-makan lokal.

Kegiatan ini telah berhasil dengan tingkat keberhasilan $100 \%$ dan mendapatkan antusiasme tinggi di masyarakat.

\section{DAFTAR PUSTAKA}

Andi M. Sadat. (2009). Brand Belief: Strategi Membagun Merek Berbasis Keyakinan. Salemba Empat: Jakarta

Geertz, Clifford. (1983). Abangan, Santri, Priyayi Dalam Masyarakat Jawa. Jakarta: PT. Dunia Pustaka Jaya

Harsojo. (1988). Pengantar Antropologi. PT. Rina Cipta. Bandung

Hertati. L. (2021). Promosi Penjualan, Audit Manajemen, Peran Audit Program Terhadap Penerimaan Kas Era Covid-19. Jurnal Economics and Digital Business Review, 2(1) 61- 86

Hertati. L., Puspitawati. P., Gantino. R., Ilyas. M. (2021). Makna Industri Kreatif Kearifan Lokal Kerajinan Limbah Pelepah Pinang Masyarakat Pinggiran Desa Mendis. Jurnal Pengabdian Nasional (JPN) Indonesia, 2 (1), 28-37

Kanada, Rabial. (2012). Baju Adat Sumsel. http://fisikasumsel.blogspot.com/2012/01/bajuadat-sumsel.html. (diakses tanggal 27 April 2021)

Pateda, Mansoer. (2010). Semantik Leksikal. Jakarta: Rineka cipta
Rokian, Ajmal. (2014). Sejarah, Khasanah Budaya dan Profil Potensi Kabupaten Banyuasin. Banyuasin: Dinas Pariwisata, Seni, Budaya, Pemuda dan Olahraga Kabupaten Banyuasin, Sumatera Selatan

Widiya, A., Hartati, L., Puspitawati, L., Gantino, R., \& Ilyas, M. (2021). Pelatihan kepada Masyarakat dalam Menjaga Makna Kearifan Lokal, Nilai Sejarah, dan Adat Khas Tradisional Masyarakat Melayu Peninggalan Kerajaan Sriwijaya. Yumary: Jurnal Pengabdian Kepada Masyarakat, 1(4), 193-201. https://doi.org/10.35912/yumary.v1i 4.224

ABDIMASY: Jurnal Pengabdian dan Pemberdayaan Masyarakat P-ISSN: 2745-7400 |E-ISSN: 2745-7419 